\section{$3 \mathrm{SC5} 4$}

\section{細胞の応答とゆらぎ}

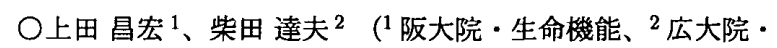
理学系)

細胞内の分子の運動や反応は確率的に起こるために、各分子の漊度は その本来の性質としてゅらいでいる。細胞内情報伝達においてシグナ ルがどのように処理され伝達されるのかを理解するためには、その過 程に伴うゆらぎ(ノイズ) との関係について考える必要がある。細胞 内の反応ネットワークは、大きなゆらぎを伴うにもかかからず、微弱 なシグナルに対する高い感度を実現している。また、ゆらぎは自発的 な運動の生成や多様性の維持など細胞が環境に適応するために持つ 柔軟な性質に不可欠の要素でもある。内らぎの影響を浼く受ける中で 情報処理を行なうために反応ネットワークはどのようにデザインされ ているのだろうか?近年、生細胞の分子イメージング技術の進展によ り、細胞内情報処理過程に伴う各情報分子の数のゆらぎを実測するこ とが可能になって来た。また、ゆらぎから反応ネットワークの構造や 機能の情報をとり出す理論解析法も進展して来た。本講演では、遗伝 子の発現ネットワークや走化性応答の情報処理ネットワークを例とし て取り挙げ、ゆらぐ世界に適応してきた細胞内反応ネットワークの特 徵を議論する。

\title{
$3 \mathrm{SC5} 5$
}

脊椎動物の発生と進化における可塑性と拘束、そし て相同性

○倉谷 滋 (理研発生・再生研究センター)

Developmental process of vertebrates can be viewed as hierarchically organized steps of epigenetic interactions that depend on developmental history of cell lineages as well as topographical relationships of cells and tissues. The gnathostome jaw is one of the most significant inventions in vertebrate evolution that seems to have incorporated alterations of tissue interactions. To address the question of how this innovation took place, we chose the lamprey, a jawless vertebrate, as a model to elucidate the mechanisms underlying the jaw evolution. We isolated jaw-patterning-related genes from the lamprey, and compared their expression patterns with those in gnathostome models. In gnathostome embryos, the early expression of Fgf8 in the ectoderm defines the MA domain in the rostral ectomesenchyme by upregulating Dlx1, the target of FGF8. Rostral to the MA, there is a Dlx1-negative area called the premandibular region that is not incorporated into the oral patterning. In contrast, the lamprey uses the entire rostral ectomesenchyme for oral patterning. Thus, the homologous gene cognates are expressed in morphologically non-homologous cell populations. From these data, we concluded that heterotopic shift of the tissue interaction, based on the same molecular cascade, was a prerequisite for the patterning of the gnathostome jaw.

S. Kuratani : Plasticity, constraints, and morphological homology in vertebrate development and evolution

\section{SD52}

\section{中性子非干涉性散乱でみるタンパク質ダイナミクス}

\section{次世代の分光技術がもたらす構造生物学の新展開 一生体高分子の動的構造解析から分子機能解明を目 指して \\ ○片岡 幹雄 ${ }^{1} 、 \bigcirc$ 城地 保昌 ${ }^{2,3}$ ( ${ }^{1}$ 奈良先端大 - 物質創成、 ${ }^{2}$ 東大・分生研、 ${ }^{3} \mathrm{CREST}, \mathrm{JST}$ )}

Proteins are molecular machines that have the fine-tuned structure evolved to perform various biological functions. The relation between structure and function is linked through dynamics as we see in ordinary machines in our daily life. In the last decades, a large number of biomolecular structures have been determined by various experimental techniques, such as X-ray crystallography and NMR spectroscopy. In the next decades, it is necessary to elucidate the nature of biomolecular dynamics in order to properly understand biomolecular function.

This symposium was planned to overview the present status and the future directions of the studies on the biomolecular dynamics. As for the experimental studies, we will focus on four potentially useful techniques, neutron scattering, Terahertz time-domain spectroscopy, Raman spectroscopy, and dielectric relaxation measurements. We would like to discuss the biomolecular dynamics obtained by these techniques, and the implication for the biomolecular function.

The theoretical study by means of molecular simulation is also essential to understand the biomolecular dynamics. Simulation reveals the detailed motion of all atoms, which cannot be accessed directly by experiments. The combination of computer simulations with the biomolecular experimental data allows us to characterize a wide range of dynamical phenomena in biomolecular systems. The recent molecular simulation study to examine possibility of detecting functionrelevant protein dynamics by inelastic neutron scattering is introduced by Y.J.

M. Kataoka and Y. Joti : Structural Biology with Advanced Biomolecular Spectroscopy: from Structural Dynamics to Function

\section{○中川洋（原研・中性子）}

Incoherent neutron scattering is one of the effective methods to investigate picosecond and nanosecond time scale dynamics of protein. In order to understand the dynamical properties of protein, the effects of hydration and temperature on the dynamics of Staphylococcal nuclease were examined by incoherent inelastic neutron scattering. At the cryogenic temperature the protein boson peak was observed in the low frequency region, and the hydration shifts the peak frequency to higher frequency. This indicates that the vibrational low frequency mode is closely coupled with the solvent. The anomalous decrease in the Debye-Waller factor at higher temperature corresponds to an increase of the mean-square displacement, which is called dynamical transition. This is accompanied by the appearance of a quasielastic scattering. The quasielastic scattering comes from anharmonic motions such as relaxation and/or stochastic motions. Hydration dependent and independent dynamical transition were observed. Analysis of quasielastic scattering could elucidate the dynamical features of the transition, which may be essential for protein function.

\footnotetext{
H.Nakagawa : Protein dynamics studied by neutron incoherent scattering
} 